\title{
Glue and glide: a novel technique for pterygium conjunctival autograft
}

This article was published in the following Dove Press journal:

Clinical Ophthalmology

\author{
Michael J Tappin' \\ Sara Sanchez-Tabernero 1,2 \\ Francesco Sabatino 1,3 \\ 'Royal Surrey County Hospital \\ NHS Foundation Trust, Guildford, \\ UK; ${ }^{2}$ Moorfields Eye Hospital NHS \\ Foundation Trust, London, UK; \\ ${ }^{3}$ Ashford \& St Peter's Hospitals NHS \\ Foundation Trust, Ashford, UK
}

\begin{abstract}
Conjunctival autograft adhesion with fibrin glue has gained rapid popularity in pterygium excision surgery and is now the technique of choice in many centers worldwide. It has enabled a suture-free technique, reducing surgical time and postoperative pain. However, the adhesive's components form a fibrin clot 10 seconds after mixing, and in this time, the surgeon must complete glue application, grabbing of the instruments and adequate placement of the conjunctival patch. This easy and new technique explains how separate application of glue components on the receiving site and cornea with subsequent sliding of graft results in even mixing of the components on site. It enables the surgeon to spend all 10 seconds in adjusting the position of the conjunctival autograft, resulting in an easier and more precise surgery.

Keywords: fibrin glue, pterygium surgery, conjunctival graft
\end{abstract}

\section{Introduction}

Conjunctival autograft adhesion with fibrin glue has gained rapid popularity in pterygium excision surgery and is now the technique of choice in many centers worldwide. It has enabled a suture-free technique, reducing surgical time and postoperative pain. ${ }^{1}$ Romano et al concluded in their recent meta-analysis that fibrin glue may result in less pterygium recurrence than sutures. ${ }^{2}$ However, the adhesive's components (fibrinogen solution and thrombin solution) form a fibrin clot 10 seconds after mixing, and in this time, the surgeon must complete glue application, grabbing of the instruments, and adequate placement of the conjunctival patch. We describe an easy and new technique that enables the surgeon to spend all 10 seconds in adjusting the position of the conjunctival autograft, leading to an easier and more precise surgery.

Institutional review board approval was not required owing to the use of the same approved surgical device as standard of care (Tisseel; Baxter International Inc., Deerfield, IL, USA). Surgeries were performed at Royal Surrey County Hospital, Guildford, London.

\section{Surgical technique}

Pterygium excision and conjunctival autograft can be performed as routinely. After de-frosting the fibrin adhesive, use separate syringes for the two components. The thick glue component (fibrinogen solution) is applied on the receiving site (Figure 1). The thin glue component (thrombin solution) is then applied on the cornea (Figure 2). It is important not to apply an excessive amount of the glue components to avoid premature mixing. Finally, conjunctival autograft is slid across the cornea onto receiving site (Figure 3). This results in even mixing of the components when the autograft is in place. See Video S1.
Correspondence: Sara Sanchez-

Tabernero

Royal Surrey County Hospital NHS

Foundation Trust, Egerton Rd, Guildford

GU2 7XX, UK

Email sara.sanchezI@nhs.net

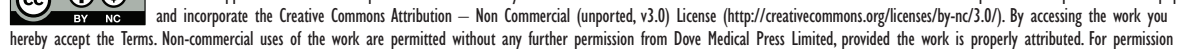
for commercial use of this work, please see paragraphs 4.2 and 5 of our Terms (https://www.dovepress.com/terms.php). 


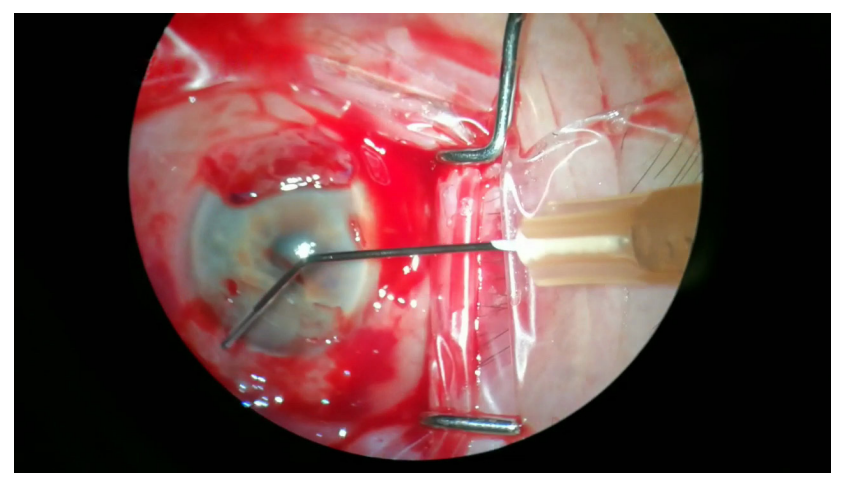

Figure I Apply thick component on receiving site.

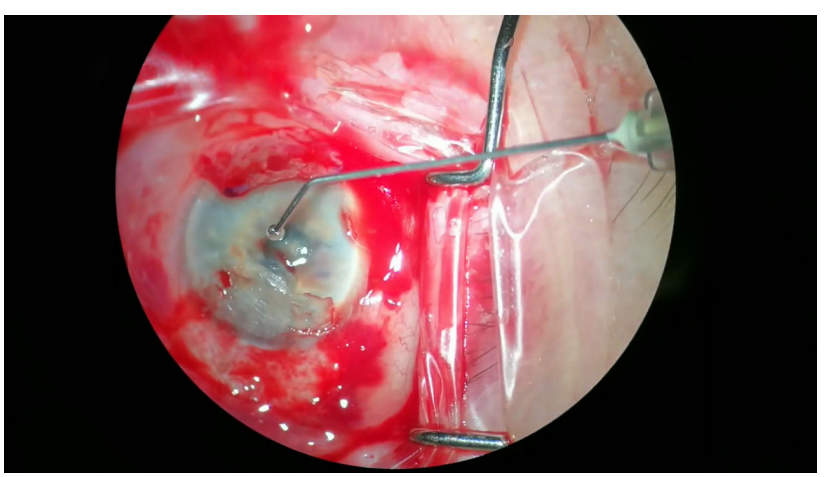

Figure 2 Apply thin component on cornea.

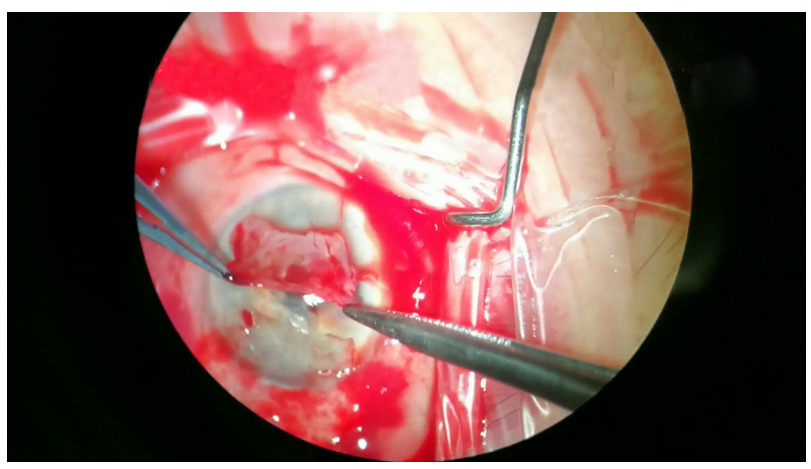

Figure 3 Slide conjunctival auto-graft.
In summary, fibrin glue has made pterygium surgery easier and faster. However, this key step can be challenging and requires quick maneuvering, with glue application, graft transfer, and adjustment in less than 10 seconds. This method of autograft gluing has, to the knowledge of the authors, never been reported before. It provides the surgeon with valuable extra time and simplifies the technique.

\section{Acknowledgment}

The authors thank Masara Laginaf, MD, Royal Surrey County Hospital, Guildford, UK, for naming the technique.

\section{Author contributions}

All authors contributed to data analysis, drafting or revising the article, gave final approval of the version to be published, and agree to be accountable for all aspects of the work.

\section{Disclosure}

The authors report no conflicts of interest in this work.

\section{References}

1. Hall RC, Logan AJ, Wells AP. Comparison of fibrin glue with sutures for pterygium excision surgery with conjunctival autografts. Clin Exp Ophthalmol. 2009;37(6):584-589.

2. Romano V, Cruciani M, Conti L, Fontana L. Fibrin glue versus sutures for conjunctival autografting in primary pterygium surgery. Cochrane Database Syst Rev. 2016;12:CD011308.
Clinical Ophthalmology

\section{Publish your work in this journal}

Clinical Ophthalmology is an international, peer-reviewed journal covering all subspecialties within ophthalmology. Key topics include: Optometry; Visual science; Pharmacology and drug therapy in eye diseases; Basic Sciences; Primary and Secondary eye care; Patient Safety and Quality of Care Improvements. This journal is indexed on
PubMed Central and CAS, and is the official journal of The Society of Clinical Ophthalmology (SCO). The manuscript management system is completely online and includes a very quick and fair peer-review system, which is all easy to use. Visit http://www.dovepress.com/ testimonials.php to read real quotes from published authors. 